\title{
Behavior of some Egyptian bread wheat genotypes under different natural photo- thermal environments
}

Sedhom A.M. Abdelkhalik* (D); Khaled E. Ragab; Adel A. Hagras

Address:

Wheat Research Department, Field Crops Research Institute (FCRI), Agricultural Research Centre (ARC), Giza, Egypt

*Corresponding author: Sedhom A. M. Abdelkhalik: sedhom aiad@yahoo.com

Received: 09.02.2021; Accepted: 17.05.2021; Published: 17.05.2021

$\underline{10.21608 / \text { ejar.2021.62280.1081 }}$

\begin{abstract}
This investigation was conducted during the 2018/2019 and 2019/2020 seasons at Sakha Agricultural Research Station, Egypt to study the influence of four planting dates on earliness and yield of fourteen wheat genotypes. The combined analyses showed highly significant differences due to years, sowing dates, genotypes and their interactions for most studied traits. December $5^{\text {th }}$ was the best sowing date for wheat production. The wheat new genotypes lines 1 and 2 had the lowest days to booting, heading, anthesis and maturity on the other side they had the highest values for grain filling period (GFP) and 1000kernel weight. Based on the genotype means, the late heading genotype (Giza 163) had short GFP (29.5 days) and possessed a high grain filling rate (233 kg ha-1 days-1). The cultivar Misr 3 was superior overall genotypes for grain yield $\left(10.529 \mathrm{t} \mathrm{ha.} .^{-1}\right)$, spikes per square meter (552 spikes), and straw yield (20.164 t ha. $\left.{ }^{-1}\right)$; and it ranked first under early sowing date (Nov. $5^{\text {th }}$ ) with $9 \%$ higher grain yield overstudied genotypes. According to stability analyses, Misr 3, Sakha 95 and Giza 171 recorded the highest yield, with the regression coefficient values $>1$. This study recommended release of new wheat genotypes (Lines 1 and 2) as new cultivars and use them to develop early maturing and heat-tolerant bread wheat genotypes in breeding programs.
\end{abstract}

Keywords: Wheat, Sowing dates, Stability, Heat susceptibility index

\section{INTRODUCTION}

Cereal food crops are the main human food source in the world. Wheat is the most important one, it is planted on about 220 million hectares worldwide, and provides one-fifth of the needs of the world's population (FAO 2019). It is one of the central pillars of food security, providing $20 \%$ of total calories and a similar portion of the total protein to the global population (Nazim Ud-Dowla et al., 2018). The total wheat production has been steadily increased in Egypt due to high yielding cultivars, favorable weather conditions, efficient use of resources, better storage facilities and governmental support for price policies. However, imports are still increasing every year to supply our growing population with wheat flour. A recent report by the U.S' Foreign Agricultural Service (FAS) in Cairo forecasts Egypt's wheat production in marketing year (MY) 2020/2021 to reach 8.9 million metric tons (MMT). As for imports, FAS Cairo forecasts Egyptian wheat imports in MY 2020/2021 at 12.85 MMT (USDA Economics, Statistics and Market Information System, March 15, 2020)

The agricultural sector is the most susceptible to climate fluctuations. Climate changes have a detrimental effect on agricultural production (Quan et al., 2019). It is expected to severely affect cropping systems and food production in many parts of the world unless local adaptation can recover these impacts (Rodríguez et al., 2019). The average yield of wheat decreases from $3 \%$ to $17 \%$ worldwide due to the severity of climate change conditions (Xie et al., 2018). To confront these changes, wheat breeders must increase efforts to improve and develop new cultivars that are higher-yielding, pest and disease resistant, more nutritious and climate-smart (Hickey et al., 2019). The genotypic response of wheat to planting dates varies for yield contributing characters due to different genetic potential (Menshawy et al., 2015, Wahid et al., 2017 and Ray \& Ahmed 2019). The grain yield is a complex character, as it significantly depending on the number of spikes per unit area, number of kernels per spike and kernel weight, so it is one of the most challenging objectives in wheat breeding (Flohr et al., 2017 and Li et al., 2019). Brdar et al. (2008) reported that grain weight, a component of yield in wheat, results from the grain filling process which is defined by two parameters: grain filling duration and grain filling rate.

Grain yield potential increases when cultivars have physical development adapted to the environment (Angus, 2006 and Harris, 2015). Identifying stable, high yielding varieties is crucial for food security (Zhongfu et al., 2018). The relative performance of yield components under heat-stressed and non-stressed environments has been commonly used as an indicator to select heat-tolerant wheat genotypes (Sharma et al., 2016). The variation can be divided into genetic and environmental variance in addition to the genetic $\times$ environmental interaction (GEI) (Warzechat et al., 2011). GEl occurs when the genotypes respond differently through environments. It is considered one of the main causes limiting progress in breeding programs and, hence, in agricultural production (Esuma et al., 2016 and Cuevas et al., 2017).

Using suitable sowing dates and promising cultivars is vital to increase wheat productivity (Wahid et al., 2017). An optimum sowing date positively impacts the grain yield of wheat, causing better adjustment to the physiology, phenology and environmental conditions (Ribeiro et al., 2009). In addition, the optimum sowing date also affects water, temperature and solar radiation available for the crop (Silva et al., 2014). Numerous authors (Anderson \& Smith 1990, Connor et al., 1992, Owiss et al., 1999, Bassu et al., 2009 and Bannayan et al., 2013) have notified an increased yield with early sowing and a reduction in yield when sowing is delayed after the optimum time and it may be due to avoid frost risk at anthesis or in regions or seasons with low frost risk, aiming at high above-ground biomass at flowering to maximize radiation interception. 
The delay in sowing date not only affects yield, but it affects the yield components (Inamullah et al., 2007 and Menshawy et al., 2015) and other aspects of the growth and development of wheat. It is generally related to a reduced kernel weight (Radmehr et al., 2003), a number of spikes per plant and per unit area (Stapper \& Fischer 1990), harvest index and number of grains per spike (Ansary et al., 1989). Accurate knowledge of the sowing window of any particular variety at a particular location is critical to achieving a high grain yield (Ortiz-Monasterio et al., 1994). The present study aimed to recognize the influence of planting dates on the performance of fourteen Egyptian bread wheat genotypes, to select the best wheat genotypes for planting under different climates.

\section{MATERIALS AND METHODS}

\section{Experimental site:}

The experiments of this study were conducted at Sakha Agricultural Research Station, Kafrelsheikh, Egypt during 2018/19 and $2019 / 20$ wheat growing seasons. The geographical location is $31^{\circ} 5^{\prime} \mathrm{N}$ latitude, $30^{\circ} 56^{\prime} \mathrm{E}$ longitude and $7 \mathrm{~m}$ above sea level, in North Delta. The weather data for the investigational site is presented in Figure (1) during the two growing seasons.

\section{Experimental design and treatments:}

The plant material comprised twelve commercial bread wheat cultivars and two national promising lines. Name and pedigree of all genotypes are shown in Table 1. These genotypes were evaluated in four sowing dates i.e., $5^{\text {th }}$ of November (early sowing), $5^{\text {th }}$ of December (close to normal sowing), $5^{\text {th }}$ of January (late sowing) and $5^{\text {th }}$ of February (very late sowing). Each sowing date in each year was considered as a separate experiment. The area of each plot was $2 \mathrm{~m}^{2}$ and consisted of 5 rows, $2 \mathrm{~m}$ long and $20 \mathrm{~cm}$ apart. Planting was done using sowing rate of 350 seeds $\mathrm{m}^{-2}$. The experiment was laid out in a Randomized Complete Block Design with three replications in each sowing date. All the wheat recommendation packages in North Delta Region were applied.

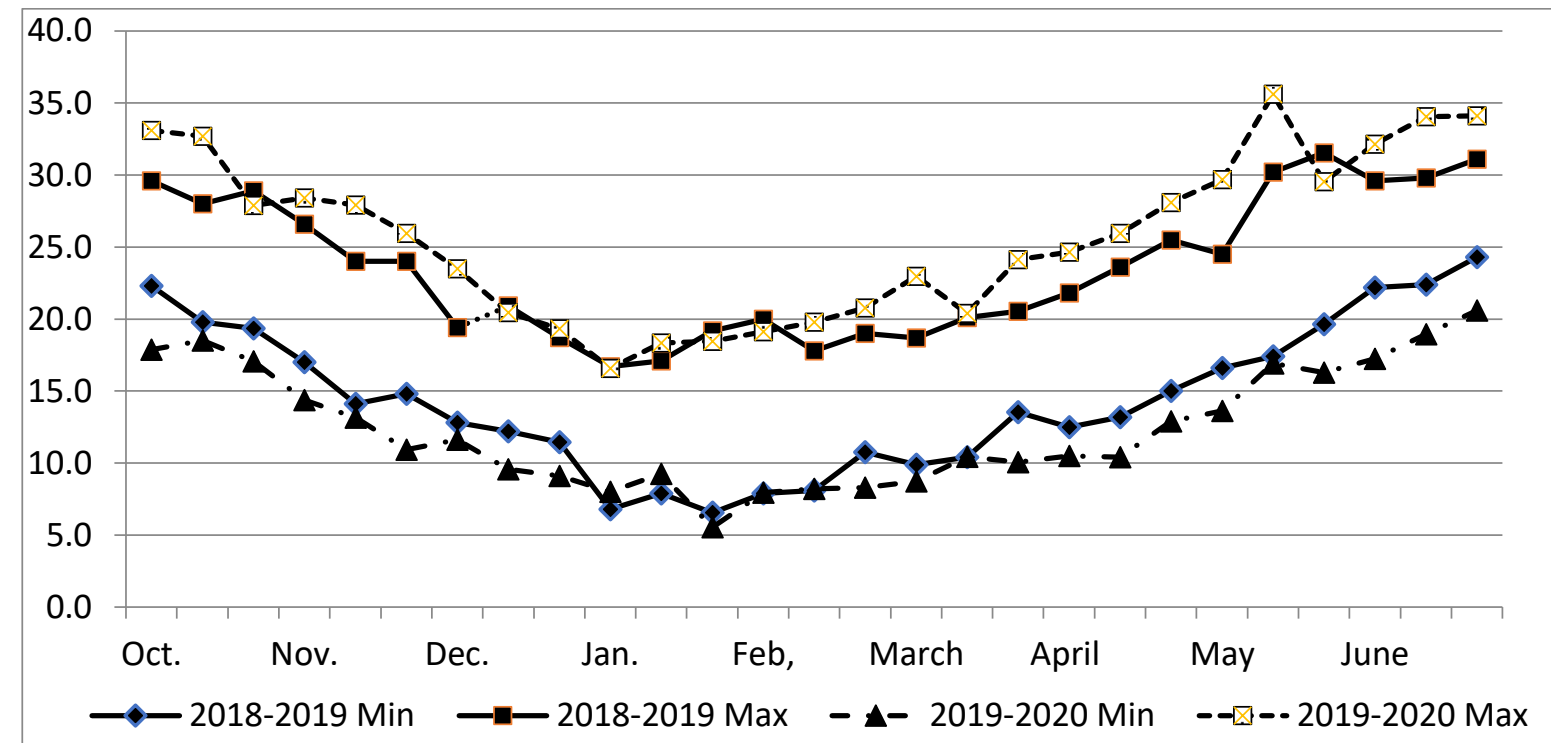

Figure 1. Average 10 days minimum (Min) and maximum (Max) temperature from October to June 2018/2019 and 2019/2020 at Sakha Agricultural Research Station.

Studied characters and data collection:

The studied characteristics consisted of earliness and agronomic components. The earliness components were: the number of days to booting (DB), to heading (DH), to anthesis (DA), and maturity (DM), grain filling period (GFP, equal to the number of days from anthesis to maturity) and grain filling rate (GFR, equal to grain yield divided by GFP). The agronomic characteristics were taken on plant height, number of spikes per square meter $\left(\mathrm{Sm}^{-2}\right)$, number of kernels per spike $\left(\mathrm{KS}^{-1}\right), 1000$-kernel weight (TKW), grain yield, straw yield and harvest index. Grain and straw yields were measured and converted into ton per hectare. In addition, the number of days to heading also was expressed as growing degree days (GDD). The GDD were calculated according to Gomez \& Richards 1997, in which GDD $=\sum\left[\left(T_{\max i}+T_{\min } i / 2-T_{b}\right]\right.$ where $T_{\max i}$ and $T_{\min i}$ are the maximum and minimum daily air temperature on the $i$ th day and $\mathrm{T}_{\mathrm{b}}$ is the base temperature below which the rate of development is assumed to be zero. Weather data were collected from the Central Laboratory for Agricultural Climate Meteorological Station, Agricultural Research Center, Ministry of Agriculture and Land Reclamation.

The heat susceptibility index (HSI) was used as a measure of heat tolerance in terms of minimization of the reduction in yield caused by unfavorable versus favorable environments. HSI was calculated in late sowing as heat stress (very late sowing versus normal sowing). For each genotype, HSI was calculated according to the formulae of Fisher \&Maurer (1978): $\mathrm{HSI}=\left(1-\mathrm{y}_{\mathrm{h}} / \mathrm{y}_{\mathrm{p}}\right) / \mathrm{H}$. Where: $y_{h}=$ mean yield in heat environment (very late sowing date), $y_{p}=$ mean yield in normal condition (potential yield), $H=h e a t$ stress intensity $=1-\left(y_{h}\right.$ of all genotypes $/ y_{p}$ of all genotypes).

The genotype main effect plus $G \times E$ interaction (GGE biplot) (Akcura and Kaya 2008) was used to visualize the $G \times E$ interaction. The $G \times$ xE analysis was conducted using R (software) package GEA-R (Version 4, 2017, CIMMYT, El Batan, Mexico) (Pacheco et al. 2018). The GGE biplot of grain yield for the studied wheat genotypes was done for the eight environmental conditions (four sowing dates $x$ two years) 


\section{Statistical analysis:}

The collected data for all variables were statistically analyzed using MSTATC statistical package microcomputer program (MSTATC, 1990) via analysis of variance using randomized complete block, one factor mode1, combined across years and sowing dates. The means of sowing dates and genotypes were obtained and differences were assessed with LSD at $5 \%$ level of probability.

Table 1. Name, pedigree, and selection history of the fourteen tested bread wheat genotypes.

\begin{tabular}{|c|c|c|}
\hline Name & Pedigree & Selection history \\
\hline Misr 1 & OASIS/SKAUZ//4*BCN/3/2*PASTOR & $\begin{array}{c}\text { CMSS00Y01881T-050M-030Y-030M-030WGY- } \\
33 \mathrm{M}-0 \mathrm{Y}-0 \mathrm{~S}\end{array}$ \\
\hline Misr 2 & SKAUZ/BAV92 & $\begin{array}{l}\text { CMSS96M03611S-1M-010SY-010M-010SY- } \\
\text { 8M-0Y-0S }\end{array}$ \\
\hline Misr 3 & ATTILA*2/PBW65*2/KACHU & $\begin{array}{l}\text { CMSS06Y00582T-099TOPM-099Y-099ZTM- } \\
\text { 099Y-099M-10WGY-0B-0EGY }\end{array}$ \\
\hline Sakha 94 & OPATA/RAYON//KAUZ & $\begin{array}{c}\text { CMBW90Y3180-0TOPM-3Y-010M-010M- } \\
\text { 010Y-I0M-015Y-0Y-0AP-0S. }\end{array}$ \\
\hline Sakha 95 & $\begin{array}{l}\text { PASTOR//SITE/MO/3/CHEN/ AEGILOPS } \\
\text { SQUARROSA(TAUS)//BCN/4/WBLL1 }\end{array}$ & $\begin{array}{l}\text { CMSA01Y00158S-040POY-040M-030ZTM- } \\
\text { 040SY-26M-OY-0SY-0S. }\end{array}$ \\
\hline Line1 & SIDS1/ATTILA//GOUMRIA-17 & S. 16498-042S-013S-21S-0S \\
\hline Line 2 & $\begin{array}{l}\text { MINO/6/SAKHA 12/5/KVZ//CNO 67/PJ 62/3/YD } \\
\text { "S"/BLO "S"/4/K134 (60)/VEE }\end{array}$ & S. $16869-010 S-07 S-1 S-2 S-0 S$ \\
\hline Giza 163 & T. AESTIVUM/BON//CNO/ 7C & CM33009-F-15M-4Y-2M-IM-1M-1Y-0M \\
\hline Giza 171 & SAKHA 93/GEMMEIZA 9 & S.6-IGZ-4GZ-IGZ-2GZ-0S \\
\hline Gemmiza 9 & ALD “S”/HUAC//CMH 74A. 630/ SX & GM 4583-5GM-1GM-0GM \\
\hline Gemmiza 12 & OTUS/3/SARA/THB//VEE & $\begin{array}{l}\text { CMSS97Y00227S-5Y-010M-010Y-010M-2Y- } \\
\text { 1M-0Y-0GM }\end{array}$ \\
\hline Sids12 & $\begin{array}{c}\text { BUC//7C/ALD/5/MAYA74/ } \\
\text { ON//1160.147/3/BB/GLL/4/CHAT"S" } \\
\text { /6/MAYA/VUL//CMH74A.630/4*SX }\end{array}$ & SD7096-4SD-1SD-1SD-0SD \\
\hline Sids 14 & BOW "S"/VEE"S"//BOW"S"/TSI/3/BANI SEWEF 1 & SD293-1SD-2SD-4SD-OSD \\
\hline Shandaweel 1 & SITE/MO/4/NAC/TH.AC//3*PVN/3/MIRLO/BUC & $\begin{array}{c}\text { CMSS93B00567S-72Y-0I0M-010Y-010M-3Y- } \\
\text { OM-0HTY-0SH }\end{array}$ \\
\hline
\end{tabular}

\section{RESULTS}

\section{Analysis of variance:}

The combined analyses showed highly significant differences $(P \leq 0.01)$ due to years, sowing dates and genotypes for all the studied traits. The differences due to the interactions between genotypes and each of years and sowing dates and interactions among genotype, sowing date and year were significant for all the studied characteristics except for GFR, SY and harvest index (supplementary Tables 1 \& 2).

The largest proportions of mean squares for most studied characteristics were due to sowing dates. Meanwhile, the proportion of mean squares due to years was higher only in three characteristics i.e., harvest index, $\mathrm{SM}^{-2}$ and $\mathrm{KS}^{-1}$. The magnitude of mean squares due to genotypes was noticed for GDD, DH, DA and TKW.

\section{Year and sowing date effect:}

The characteristics $\mathrm{DB}, \mathrm{DH}, \mathrm{DA}$ and $\mathrm{DM}$, plant height, $\mathrm{SM}^{-2}$ and straw yield recorded significantly higher values in the first season comparing to the second, while the remaining studied characters recorded significantly higher values in the second season (Tables 2 \& 3 and supplementary Table S3). It was interesting to notice that growing degree days' estimates did not differ significantly between the two seasons. In this respect, the first season recorded higher degrees of minimum and lower degrees of maximum temperature during most of the growing season while the second season was vice versa (Fig.1).

In general, the first and second sowing dates ( $5^{\text {th }}$ November and $5^{\text {th }}$ December) recorded the highest mean values for most studied characteristics. The first sowing date recorded the highest mean values for DM, GDD and GFP. Meanwhile, the highest mean values for $\mathrm{DB}, \mathrm{DH}, \mathrm{DA}, \mathrm{GFR}$, plant height, grain yield, $\mathrm{KS}^{-1}, \mathrm{TKW}$ and straw yield recorded in the second sowing date.

\section{Genotype effect:}

Genotype effects were highly significant on all studied traits when the data were combined across years and planting dates. Therefore; the comparisons among genotypic means are valid. The least values of DB, DH, DA and DM recorded by Lines 1 and 2 . Also, they recorded the highest values for GFP and TKW where the differences were significant with most of the remaining genotypes.

Line 2 was the earliest genotypes, it's recorded the least number of DB, DH, DA and DM and lowest GDD. Both Lines 2 and 1 reached heading after accumulation of the lowest thermal units (1023 and 1056 units, respectively). The shortest GFP (29.5 days) was recorded for Giza 163 followed by Gemmiza 9, Sakha 95 and Misr 2. Based on the genotype means, the late heading genotypes 
had short GFP and possessed high GFR, while the reverse was found for early ones. The highest GFR was recorded for Sakha 95 (279 $\mathrm{kg} \mathrm{day}^{-1} \mathrm{ha}^{-1}$ ) followed by Sakha 94 and Misr 3. These results are in accordance with the findings of Menshawy (2007) who reported that the genotypes which had long GFP showed low GFR in general.

Table 2. Mean values of earliness characters for fourteen bread wheat genotypes grown under four sowing dates during the two growing 2018/2019 and 2019/2020 seasons.

\begin{tabular}{|c|c|c|c|c|c|}
\hline Variable & DH† & DM & GFP (day) & GFR (kg/ha/day) & GDD $\left({ }^{\circ} \mathrm{C}\right)$ \\
\hline \multicolumn{6}{|c|}{ Year } \\
\hline $2018 / 2019$ & 88.3 & 137.9 & 39.6 & 230.6 & 1242.8 \\
\hline $2019 / 2020$ & 83.3 & 132.7 & 40.3 & 248.7 & 1244.4 \\
\hline$F$ test & ** & $* *$ & $* *$ & $* *$ & Ns \\
\hline \multicolumn{6}{|c|}{ Sowing date } \\
\hline Nov. $5^{\text {th }}$ & 88.3 & 154.6 & 51.9 & 210.8 & 1369.8 \\
\hline Dec. $5^{\text {th }}$ & 96.8 & 146.4 & 39.4 & 275.6 & 1325.8 \\
\hline Jan. $5^{\text {th }}$ & 86.2 & 130.6 & 37.5 & 259.0 & 1183.2 \\
\hline Feb. $5^{\text {th }}$ & 71.9 & 109.5 & 31.0 & 213.3 & 1095.5 \\
\hline LSD $_{0.05}$ & 0.4 & 0.4 & 0.5 & 8.8 & 6.9 \\
\hline \multicolumn{6}{|c|}{ Genotype } \\
\hline Misr 1 & 86.8 & 134.6 & 40.0 & 245.8 & 1252.6 \\
\hline Misr 2 & 90.0 & 137.8 & 37.8 & 246.0 & 1298.8 \\
\hline Misr 3 & 85.5 & 136.6 & 41.4 & 255.7 & 1233.1 \\
\hline Sakha 94 & 88.7 & 134.9 & 38.0 & 256.0 & 1282.6 \\
\hline Sakha 95 & 87.5 & 134.8 & 37.7 & 279.0 & 1260.9 \\
\hline Line 1 & 72.5 & 128.2 & 46.0 & 223.9 & 1056.2 \\
\hline Line 2 & 70.3 & 127.8 & 46.8 & 218.9 & 1023.2 \\
\hline Giza 163 & 105.7 & 143.3 & 29.5 & 233.5 & 1553.0 \\
\hline Giza 171 & 85.7 & 137.0 & 42.3 & 248.6 & 1240.4 \\
\hline Gemmiza 9 & 90.5 & 138.2 & 37.6 & 235.2 & 1315.5 \\
\hline Gemmiza 12 & 85.0 & 134.2 & 41.1 & 217.6 & 1228.1 \\
\hline Sids12 & 79.8 & 133.1 & 42.8 & 208.3 & 1152.2 \\
\hline Sids 14 & 88.6 & 136.1 & 38.0 & 258.7 & 1284.2 \\
\hline Shandaweel 1 & 84.9 & 137.4 & 40.5 & 228.2 & 1229.3 \\
\hline LSD $_{0.05}$ & 0.79 & 0.76 & 0.93 & 16.41 & 12.95 \\
\hline
\end{tabular}

DH; number of days to heading, DM: number of days to maturity, GFP: grain filling period, GFR: grain filling rate, GDD: growing degree days.

Table 3. Mean effects of yield characters and harvest index for fourteen bread wheat genotypes grown under four sowing dates during the two growing seasons 2018/2019 and 2019/2020.

\begin{tabular}{|c|c|c|c|c|c|}
\hline Variable & Grain yield $\left(\mathrm{t} \mathrm{ha}^{-1}\right)$ & $S^{-2} †$ & $\mathrm{KS}^{-1}$ & TKW (g) & Harvest index (\%) \\
\hline \multicolumn{6}{|c|}{ Year } \\
\hline $2018 / 2019$ & 9.013 & 545 & 53.0 & 41.3 & 32.4 \\
\hline $2019 / 2020$ & 9.913 & 424 & 63.4 & 43.0 & 37.9 \\
\hline F test & $* *$ & $* *$ & $* *$ & $* *$ & $* *$ \\
\hline \multicolumn{6}{|c|}{ Sowing date } \\
\hline Nov. $5^{\text {th }}$ & 10.717 & 472 & 60.4 & 45.2 & 34.9 \\
\hline Dec. $5^{\text {th }}$ & 10.783 & 508 & 60.6 & 45.6 & 34.8 \\
\hline Jan. $5^{\text {th }}$ & 9.685 & 518 & 58.5 & 42.4 & 37.6 \\
\hline Feb. $5^{\text {th }}$ & 6.667 & 441 & 53.2 & 35.5 & 33.3 \\
\hline LSD $_{0.05}$ & 0.321 & 23.64 & 2.04 & 1.34 & 1.07 \\
\hline \multicolumn{6}{|c|}{ Genotype } \\
\hline Misr 1 & 9.838 & 547 & 55.8 & 41.8 & 35.7 \\
\hline Misr 2 & 9.331 & 542 & 62.5 & 37.8 & 32.1 \\
\hline Misr 3 & 10.529 & 552 & 52.3 & 43.7 & 34.5 \\
\hline Sakha 94 & 9.685 & 489 & 57.5 & 41.1 & 38.9 \\
\hline Sakha 95 & 10.517 & 515 & 56.0 & 44.2 & 37.9 \\
\hline Line 1 & 10.025 & 497 & 52.9 & 44.5 & 39.0 \\
\hline Line 2 & 9.878 & 469 & 51.6 & 49.4 & 40.3 \\
\hline Giza 163 & 7.022 & 440 & 52.9 & 37.7 & 27.0 \\
\hline Giza 171 & 10.347 & 425 & 62.6 & 46.8 & 35.9 \\
\hline Gemmiza 9 & 8.87 & 444 & 59.9 & 40.6 & 31.8 \\
\hline Gemmiza 12 & 8.867 & 463 & 59.6 & 41.5 & 34.8 \\
\hline Sids12 & 8.626 & 376 & 69.2 & 40.2 & 38.0 \\
\hline Sids 14 & 9.898 & 495 & 60.0 & 43.8 & 33.5 \\
\hline Shandaweel 1 & 9.045 & 531 & 61.8 & 37.2 & 32.7 \\
\hline LSD $_{0.05}$ & 0.60 & 44.23 & 3.82 & 2.52 & 2.00 \\
\hline
\end{tabular}

+ SM-2: number of spikes per square meter, $\mathrm{KS}^{-1}$ : number of kernels per spike, TKW: one thousand kernel weight. 


\section{Interaction effects:}

All factors except genotypes and sowing dates were considered random. Therefore, only the most interesting interactions, genotypes $\times$ sowing dates, will be discussed. Interaction effects presented in Tables 4 and 5 and supplementary Table S5 showed that Line 2 and Line 1 recorded the lowest values for DB, DH, under the first sowing date and for DA, DM and GDD under the fourth sowing date. Meanwhile, Giza 163 recorded the highest values for DB, DH, DA, DM and GDD under the first sowing date. The shortest GFP was recorded for Giza 163 under the fourth sowing date while the longest one was recorded for Line 2 under the first sowing date. The highest GFR was recorded for both Misr 2 and Giza 163 under the second sowing date, while the lowest one was recorded by Giza 163 under the fourth sowing dates.

The results of this study indicated that there are some genotypes performed well under specific sowing date and did not differ significantly in their grain yield (Figure 3). Under the first sowing date (5th Nov.), the highest grain yield was produced by Misr 3, Sids 14, Sakha 95 and Giza 171. The highest grain yield under the second sowing date (5th Dec.) was produced by Sakha 95, Misr 2, Misr 1, Giza 171, Misr 3, Sids 14 and Line 1. Under the third sowing date (5th Jan.), the highest grain yield was produced by Misr 3, Sakha 95, Sids 14, Giza 171, Line 2, Sakha 94 and Misr 2. The highest grain yield under the fourth sowing date (5 $5^{\text {th }}$ Feb.) was produced by Line 1, Line 2, Sids 12, Giza 171 and Sakha 95.

The highest values for $\mathrm{SM}^{-2}$ were recorded by Shandaweel 1 on $5^{\text {th }}$ Nov., Line 1 on $5^{\text {th }}$ Dec., Sids 14 on $5^{\text {th }}$ Jan. and Misr 3 on $5^{\text {th }}$ Feb. sowing date. It was interesting to notice that the three cultivars Misr 1, Misr 2 and Misr 3 were among the highest genotypes in SM2 in all the tested sowing dates. Out of the tested 14 genotypes, 5 to 9 genotypes did not differ significantly in their $\mathrm{SM}^{-2}$ with the highest ones, where the highest number of such genotypes was on $5^{\text {th }}$ Jan. followed by $5^{\text {th }}$ Feb. then $5^{\text {th }}$ Dec. and $5^{\text {th }}$ Nov.

The highest KS-1 was recorded by the cultivar Sids 12 in the first, second and fourth sowing dates while it was recorded by Misr 2 in the third sowing date with an insignificant difference from that of Sids 12. At least three cultivars did not differ significantly in their $\mathrm{KS}^{-1}$ from the highest cultivar in each of the four sowing dates. From these cultivars Giza 171 in the second, third and fourth sowing dates and Shandaweel 1 in the first, third and fourth sowing dates.

The highest values for TKW was recorded by Line 2 in the first, third and fourth sowing dates. Meanwhile, the highest value was recorded by Giza 171 in the second sowing date and did not differ significantly from that of Line 2 in the other three sowing dates. The following genotypes recorded high values for TKW and their values did not differ significantly from that of the highest genotype; Line 1 in the first, third and fourth sowing dates; Misr 3 in the first and third sowing dates; Sakha 95 in the second and third sowing dates; Sids 14 in the third and fourth sowing dates.

The tallest plants were recorded by Sids 14 in $5^{\text {th }}$ Dec. sowing date and its value did not differ significantly from that of the tallest plants in the first and third sowing date. Both cultivars Misr2 and Giza 163 recorded the tallest plants in the first, third and fourth sowing dates, respectively. The following three cultivars recorded high values for plant height and their values did not differ significantly from that of the tallest ones; Sakha 95 on $5^{\text {th }}$ Nov., Giza 171 on $5^{\text {th }}$ Dec., Gemmiza 9 on $5^{\text {th }}$ Jan. sowing dates.

The highest SY was recorded for Sids 14 on $5^{\text {th }}$ Dec. followed by Gemmiza 9 on $5^{\text {th }}$ Nov. then Sids 14 on $5^{\text {th }}$ Jan. and Giza 163 on $5^{\text {th }}$ Feb. sowing date. Misr 3 recorded high values for SY yield in the four sowing dates and its values did differ significantly from that of the highest cultivars. In addition, both Misr 2 and Shandaweel 1 cultivars recorded high values under the first and third sowing dates. The following cultivars recorded their high values under specific sowing date; Sakha 95 on $5^{\text {th }}$ Nov., Gemmiza 9 , Giza 171 and Gemmiza 12 on $5^{\text {th }}$ Jan sowing date.

The highest harvest index value was recorded for Sids 12 on $5^{\text {th }}$ Feb. sowing date followed by Line 2 on both $5^{\text {th }}$ Jan. and $5^{\text {th }}$ Nov. sowing dates, and then Sakha 94 on $5^{\text {th }}$ Dec. sowing date. Line 1 recorded high values for harvest index under the four sowing dates and its value did not differ significantly from that of the highest genotypes. Sakha 95 was among recorded the highest harvest index genotypes under both $5^{\text {th }}$ Dec. and $5^{\text {th }}$ Jan. The differences were insignificant between values of the following genotypes and that of best genotypes in the harvest index; Giza 171 on $5^{\text {th }}$ Nov., both Misr 1 and Misr 2 on $5^{\text {th }}$ Dec., and Sakha 94 on $5^{\text {th }}$ Jan sowing date.

\section{Stability analysis:}

Combined analysis of variance revealed that genotypes (G), environments (E) and their interaction (GEI) mean squares had a highly significant effect on grain yield of the studied wheat genotypes across 8 environments, i.e. 4 sowing dates in 2-years (supplementary Table 4). Singh and Narayanan (2000) reported that, if GEl interaction is found to be significant, the stability analysis can be carried out. Environments effects accounted for the largest proportion of sums of squares (57.21\%) followed by genotypic effects $(14.57 \%)$ then GEl effects captured (14.13\%), all terms being highly significant. Environmental variation was conquered by the sowing date effect.

GGE biplot analyses for comparison of genotypes were performed to detect the ideal and desirable genotypes (Figure 2). An ideal genotype should have both high mean yield performance and high stability across environments (Kaya et al. 2006 and Yan and Tinker 2006). Giza 171, Sakha 95 and Misr 3 (G9, G5 and G4, respectively) were the desirable genotypes as they grouped in the centric circle. However, Giza 163 (G8) seems to be undesirable.

In the ranking of genotypes based on their performance in all environments, a line is drawn that passes through the biplot origin and the environment. This line is called the axis for the environment (Yan and Tinker 2006) and along it is the ranking of genotype. Thus, Figure 3 showed rank of genotypes performance. From the graph, the highest yielder genotype was Giza 171 (G9) followed by Sakha 95 (G5) and Misr 3 (G3) but Giza 171 showed more stability. In the contrast, Giza 163 (G8) was the lowest. 
Table 4. Mean values over two years (2018/19 and 2019/20) for days to heading, days to maturity, grain filling period, grain filling rate and growing degree days of fourteen bread wheat genotypes grown under four sowing dates.

\begin{tabular}{|c|c|c|c|c|c|c|c|c|c|c|c|c|c|c|c|c|c|c|c|c|}
\hline \multirow[b]{2}{*}{ Genotype } & \multicolumn{4}{|c|}{ Days to heading } & \multicolumn{4}{|c|}{ Days to maturity } & \multicolumn{4}{|c|}{ Grain filling period (day) } & \multicolumn{4}{|c|}{ Grain filling rate $\left(\mathrm{kg} \mathrm{ha}^{-1} \mathrm{day}^{-1}\right)$} & \multicolumn{4}{|c|}{ Growing degree days $\left({ }^{\circ} \mathrm{C}\right)$} \\
\hline & $\begin{array}{l}5^{\text {th }} \\
\text { Nov. }\end{array}$ & $\begin{array}{l}5^{\text {th }} \\
\text { Dec }\end{array}$ & $\begin{array}{l}5^{\text {th }} \\
\text { Jan. }\end{array}$ & $\begin{array}{c}5^{\text {th }} \\
\text { Feb. }\end{array}$ & $\begin{array}{l}5^{\text {th }} \\
\text { Nov. }\end{array}$ & $\begin{array}{c}5^{\text {th }} \\
\text { Dec. }\end{array}$ & $\begin{array}{c}5^{\text {th }} \\
\text { Jan. }\end{array}$ & $\begin{array}{l}5^{\text {th }} \\
\text { Feb. }\end{array}$ & $\begin{array}{l}5^{\text {th }} \\
\text { Nov. }\end{array}$ & $\begin{array}{c}5^{\text {th }} \\
\text { Dec. }\end{array}$ & $\begin{array}{c}5^{\text {th }} \\
\text { Jan. }\end{array}$ & $\begin{array}{l}5^{\text {th }} \\
\text { Feb. }\end{array}$ & $\begin{array}{c}5^{\text {th }} \\
\text { Nov. }\end{array}$ & $\begin{array}{c}5^{\text {th }} \\
\text { Dec. }\end{array}$ & $\begin{array}{l}5^{\text {th }} \\
\text { Jan. }\end{array}$ & $\begin{array}{c}5^{\text {th }} \\
\text { Feb. }\end{array}$ & $\begin{array}{c}5^{\text {th }} \\
\text { Nov. }\end{array}$ & $\begin{array}{c}5^{\text {th }} \\
\text { Dec. }\end{array}$ & $\begin{array}{c}5^{\text {th }} \\
\text { Jan. }\end{array}$ & $\begin{array}{c}5^{\text {th }} \\
\text { Feb. }\end{array}$ \\
\hline Misr 1 & 94 & 97 & 85 & 71 & 155 & 145 & 129 & 109 & 49.3 & 40.7 & 38.3 & 31.5 & 228.7 & 292.2 & $\begin{array}{c}246 . \\
4\end{array}$ & 216.0 & 1436 & 1326 & 1165 & 1084 \\
\hline Misr 2 & 99 & 99 & 88 & 73 & 161 & 148 & 132 & 110 & 45.7 & 37.0 & 37.5 & 30.8 & 213.5 & 322.1 & $\begin{array}{c}266 . \\
2\end{array}$ & 182.3 & 1509 & 1362 & 1207 & 1118 \\
\hline Misr 3 & 88 & 97 & 87 & 71 & 157 & 148 & 133 & 109 & 55.2 & 41.3 & 38.3 & 30.8 & 228.6 & 277.7 & $\begin{array}{c}293 . \\
4\end{array}$ & 223.1 & 1354 & 1321 & 1188 & 1070 \\
\hline Sakha 94 & 95 & 99 & 88 & 73 & 155 & 147 & 130 & 108 & 47.5 & 38.3 & 36.7 & 29.5 & 229.4 & 278.5 & $\begin{array}{c}275 . \\
9\end{array}$ & 240.1 & 1456 & 1362 & 1205 & 1107 \\
\hline Sakha 95 & 96 & 97 & 86 & 72 & 156 & 146 & 128 & 110 & 45.3 & 39.0 & 35.3 & 31.0 & 255.3 & 309.8 & $\begin{array}{c}313 . \\
3\end{array}$ & 237.8 & 1469 & 1318 & 1168 & 1089 \\
\hline Line 1 & 63 & 85 & 77 & 66 & 141 & 140 & 126 & 107 & 62.7 & 44.7 & 40.3 & 36.5 & 170.3 & 255.2 & $\begin{array}{c}236 . \\
3\end{array}$ & 233.8 & 1056 & 1149 & 1033 & 987 \\
\hline Line 2 & 60 & 81 & 75 & 64 & 142 & 138 & 126 & 106 & 66.2 & 44.5 & 40.5 & 36.0 & 159.8 & 243.3 & $\begin{array}{c}255 . \\
4\end{array}$ & 217.0 & 1020 & 1099 & 1011 & 963 \\
\hline Giza 163 & 127 & 112 & 96 & 87 & 170 & 152 & 134 & 117 & 34.7 & 28.2 & 29.8 & 25.2 & 261.7 & 315.4 & $\begin{array}{c}259 . \\
7\end{array}$ & 97.1 & 1895 & 1562 & 1361 & 1393 \\
\hline Giza 171 & 84 & 98 & 89 & 72 & 154 & 150 & 133 & 111 & 56.7 & 41.7 & 39.5 & 31.5 & 203.3 & 282.1 & $\begin{array}{c}269 . \\
5\end{array}$ & 239.6 & 1304 & 1342 & 1217 & 1099 \\
\hline Gemmiza 9 & 95 & 101 & 90 & 76 & 159 & 150 & 133 & 111 & 49.0 & 38.3 & 35.0 & 28.2 & 222.3 & 265.1 & $\begin{array}{c}245 . \\
7\end{array}$ & 207.8 & 1456 & 1394 & 1253 & 1160 \\
\hline Gemmiza 12 & 86 & 97 & 86 & 71 & 153 & 145 & 131 & 108 & 53.2 & 40.8 & 39.3 & 31.2 & 190.4 & 247.0 & $\begin{array}{c}219 . \\
9\end{array}$ & 213.0 & 1330 & 1324 & 1177 & 1081 \\
\hline Sids12 & 76 & 94 & 83 & 67 & 150 & 145 & 130 & 108 & 57.0 & 41.8 & 39.7 & 32.5 & 160.2 & 215.6 & $\begin{array}{c}217 . \\
6\end{array}$ & 239.7 & 1208 & 1278 & 1124 & 999 \\
\hline Sids 14 & 91 & 101 & 90 & 73 & 156 & 148 & 132 & 109 & 48.5 & 37.5 & 37.2 & 28.7 & 241.5 & 302.7 & $\begin{array}{c}287 . \\
1 \\
\end{array}$ & 203.6 & 1401 & 1384 & 1240 & 1112 \\
\hline Shandaweel 1 & 82 & 98 & 89 & 71 & 157 & 149 & 134 & 110 & 55.3 & 38.0 & 37.8 & 30.7 & 185.9 & 252.2 & $\begin{array}{c}239 . \\
2\end{array}$ & 235.6 & 1285 & 1339 & 1218 & 1076 \\
\hline LSD $_{0.05}$ & \multicolumn{4}{|c|}{1.6} & \multicolumn{4}{|c|}{1.5} & \multicolumn{4}{|c|}{1.9} & \multicolumn{4}{|c|}{32.8} & \multicolumn{4}{|c|}{25.9} \\
\hline
\end{tabular}


Table 5. Mean values over two years (2018/19 and 2019/20) for grain yield, spikes per square meter, kernels per spike, 1000-kernel weight, and harvest index of fourteen bread wheat genotypes grown under four sowing dates

\begin{tabular}{|c|c|c|c|c|c|c|c|c|c|c|c|c|c|c|c|c|c|c|c|c|}
\hline \multirow[b]{2}{*}{ Genotype } & \multicolumn{4}{|c|}{ Grain yield (ton ha. ${ }^{-1}$ ) } & \multicolumn{4}{|c|}{ Spikes per square meter } & \multicolumn{4}{|c|}{ Kernels per spike } & \multicolumn{4}{|c|}{ 1000-kernel weight (g) } & \multicolumn{4}{|c|}{ Harvest index (\%) } \\
\hline & $\begin{array}{c}5^{\text {th }} \\
\text { Nov. }\end{array}$ & $\begin{array}{l}5^{\text {th }} \\
\text { Dec. }\end{array}$ & $\begin{array}{c}5^{\text {th }} \\
\text { Jan. }\end{array}$ & $\begin{array}{c}5^{\text {th }} \\
\text { Feb. }\end{array}$ & $\begin{array}{c}5^{\text {th }} \\
\text { Nov. }\end{array}$ & $\begin{array}{c}5^{\text {th }} \\
\text { Dec. }\end{array}$ & $\begin{array}{c}5^{\text {th }} \\
\text { Jan. }\end{array}$ & $\begin{array}{l}5^{\text {th }} \\
\text { Feb. }\end{array}$ & $\begin{array}{c}5^{\text {th }} \\
\text { Nov. }\end{array}$ & $\begin{array}{c}5^{\text {th }} \\
\text { Dec. }\end{array}$ & $\begin{array}{c}5^{\text {th }} \\
\text { Jan. }\end{array}$ & $\begin{array}{c}5^{\text {th }} \\
\text { Feb. }\end{array}$ & $\begin{array}{c}5^{\text {th }} \\
\text { Nov. }\end{array}$ & $\begin{array}{c}5^{\text {th }} \\
\text { Dec. }\end{array}$ & $\begin{array}{c}5^{\text {th }} \\
\text { Jan. }\end{array}$ & $\begin{array}{c}5^{\text {th }} \\
\text { Feb. }\end{array}$ & $\begin{array}{c}5^{\text {th }} \\
\text { Nov. }\end{array}$ & $\begin{array}{c}5^{\text {th }} \\
\text { Dec. }\end{array}$ & $\begin{array}{c}5^{\text {th }} \\
\text { Jan. }\end{array}$ & $\begin{array}{c}5^{\text {th }} \\
\text { Feb. }\end{array}$ \\
\hline Misr 1 & 11.30 & 11.83 & 9.44 & 6.79 & 585 & 572 & 535 & 497 & 60.9 & 57.4 & 52.1 & 52.9 & 44.9 & 47.4 & 42.3 & 32.8 & 34.8 & 35.9 & 39.4 & 32.7 \\
\hline Misr 2 & 9.75 & 11.97 & 10.00 & 5.61 & 546 & 610 & 512 & 501 & 62.8 & 62.9 & 66.8 & 57.5 & 42.5 & 39.6 & 39.2 & 29.8 & 29.6 & 36.4 & 35.3 & 26.8 \\
\hline Misr 3 & 12.58 & 11.49 & 11.19 & 6.86 & 540 & 607 & 546 & 517 & 54.1 & 47.7 & 57.7 & 49.7 & 49.2 & 46.0 & 43.4 & 36.1 & 36.1 & 32.9 & 38.8 & 30.1 \\
\hline Sakha 94 & 10.90 & 10.65 & 10.11 & 7.09 & 488 & 494 & 519 & 454 & 64.3 & 57.5 & 57.0 & 51.3 & 41.9 & 43.4 & 41.9 & 37.3 & 36.6 & 39.4 & 41.2 & 38.5 \\
\hline Sakha 95 & 11.58 & 12.07 & 11.05 & 7.37 & 545 & 511 & 567 & 436 & 57.7 & 58.3 & 53.6 & 54.3 & 47.0 & 52.1 & 43.2 & 34.5 & 33.8 & 37.6 & 41.4 & 38.7 \\
\hline Line 1 & 10.65 & 11.39 & 9.53 & 8.53 & 396 & 612 & 512 & 470 & 48.9 & 54.3 & 57.5 & 51.0 & 51.3 & 45.8 & 43.5 & 37.4 & 37.9 & 36.8 & 40.1 & 41.2 \\
\hline Line 2 & 10.55 & 10.83 & 10.35 & 7.79 & 346 & 525 & 567 & 439 & 47.9 & 56.3 & 54.1 & 48.2 & 54.6 & 52.6 & 48.1 & 42.4 & 41.5 & 36.4 & 43.4 & 40.0 \\
\hline Giza 163 & 9.09 & 8.88 & 7.69 & 2.43 & 425 & 416 & 504 & 417 & 55.1 & 65.1 & 56.6 & 34.8 & 35.9 & 42.1 & 40.6 & 32.3 & 30.9 & 32.8 & 32.6 & 11.8 \\
\hline Giza 171 & 11.50 & 11.69 & 10.66 & 7.55 & 404 & 405 & 549 & 341 & 60.6 & 68.1 & 61.5 & 60.3 & 51.5 & 53.2 & 44.0 & 38.4 & 37.4 & 33.7 & 37.4 & 35.1 \\
\hline Gemmiza 9 & 10.92 & 10.16 & 8.54 & 5.86 & 443 & 433 & 505 & 395 & 69.3 & 57.1 & 57.5 & 55.7 & 43.7 & 44.8 & 41.2 & 32.5 & 31.6 & 33.2 & 33.0 & 29.5 \\
\hline Gemmiza 12 & 10.13 & 10.04 & 8.65 & 6.65 & 441 & 496 & 469 & 446 & 60.5 & 64.6 & 58.3 & 54.9 & 44.2 & 43.6 & 42.3 & 35.8 & 36.3 & 33.9 & 33.5 & 35.4 \\
\hline Sids12 & 9.08 & 9.01 & 8.64 & 7.77 & 374 & 377 & 438 & 315 & 74.1 & 72.2 & 65.9 & 64.5 & 41.4 & 43.2 & 39.9 & 36.3 & 34.7 & 33.8 & 39.9 & 43.6 \\
\hline Sids 14 & 11.68 & 11.42 & 10.66 & 5.83 & 462 & 524 & 568 & 427 & 65.9 & 64.6 & 56.4 & 53.2 & 48.4 & 45.8 & 43.4 & 37.8 & 35.8 & 31.6 & 36.9 & 29.6 \\
\hline Shandaweel 1 & 10.33 & 9.55 & 9.08 & 7.23 & 609 & 537 & 460 & 516 & 64.0 & 62.4 & 63.9 & 57.1 & 36.0 & 38.4 & 40.4 & 33.9 & 32.1 & 32.2 & 33.2 & 33.4 \\
\hline $\operatorname{LSD}_{0.05}$ & \multicolumn{4}{|c|}{1.2} & \multicolumn{4}{|c|}{88} & \multicolumn{4}{|c|}{7.6} & \multicolumn{4}{|c|}{5.0} & \multicolumn{4}{|c|}{4.0} \\
\hline
\end{tabular}


One of the most attractive features of GGE biplot is its ability to show the "which-won-where" pattern of a genotype by environment dataset as it graphically addresses important concepts such as cross-over GE, mega-environment differentiation, specific adaptation, etc. (Yan and Tinker 2006). The polygon view of the GGE biplot (Figure 4) indicates the best genotype(s) in each environment and groups of environments (Yan et al., 2000 and Yan and Hunt 2001). Sakha 95 (G5) and Misr 3 (G3) gave high yield at Nov. $5^{\text {th }}, 2019$, Jan. $5^{\text {th }}, 2020$ and Jan. $5^{\text {th }}, 2019$ sowing dates (E5, E7 and E3), Giza 171 (G9) gave high yield at Nov. $5^{\text {th }}, 2018$, Dec. $5^{\text {th }}, 2018$ and Jan. $5^{\text {th }}, 2019$ sowing dates (E1, E2 and E3), Line 1 (G6) gave high yield at Feb. $5^{\text {th }}, 2019$ and Feb. $5^{\text {th }}, 2020$ sowing dates (E4 and E8) and Sids 14 (G13) gave high yield on Dec. $5^{\text {th }}, 2019$ sowing dates (E6). The other genotypes lying on the vertices did not respond at any of the environments.

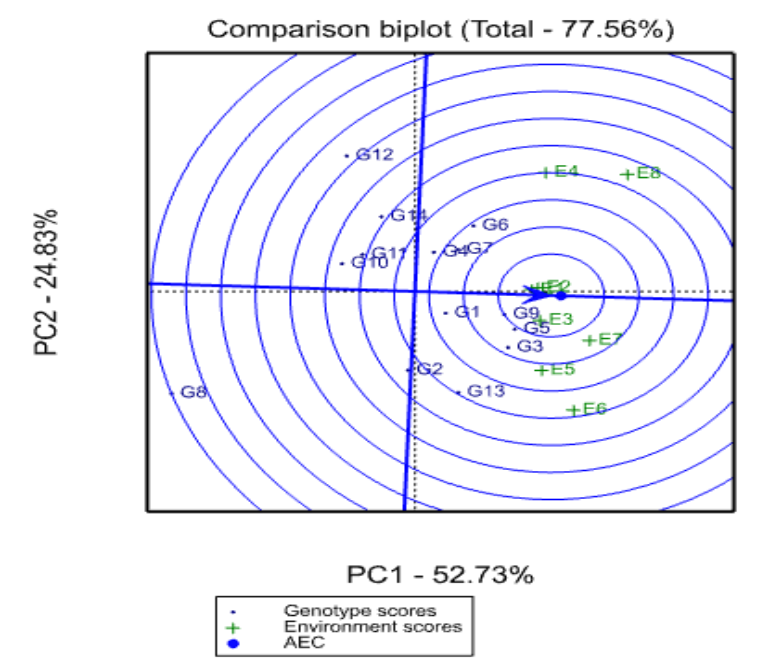

Figure 2. GGE-biplot focused scaling for comparison of the genotypes. E1-E8 are the environments; G1G14 are the genotypes.

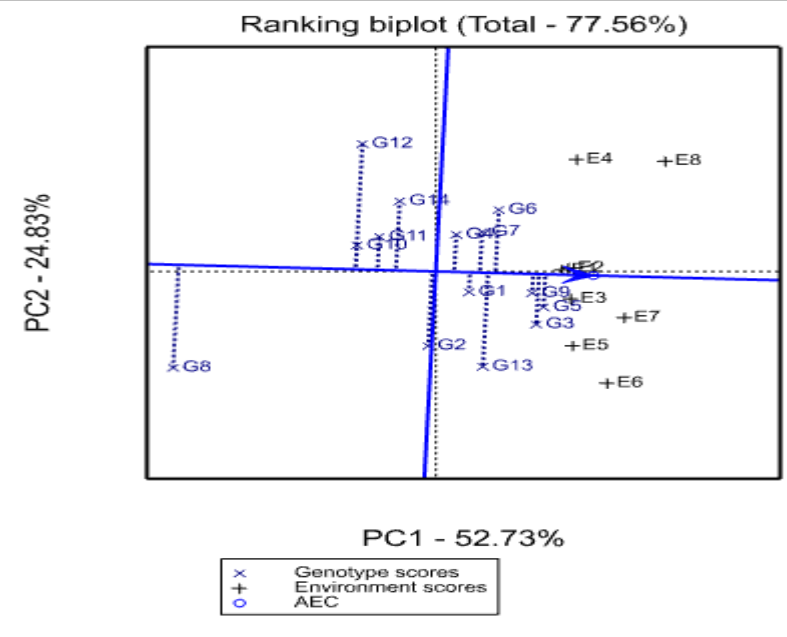

Figure 3. Identification of winnig genotypes across 8 environments. E1 -E8 are the environments; G1-G14 are the genotypes.

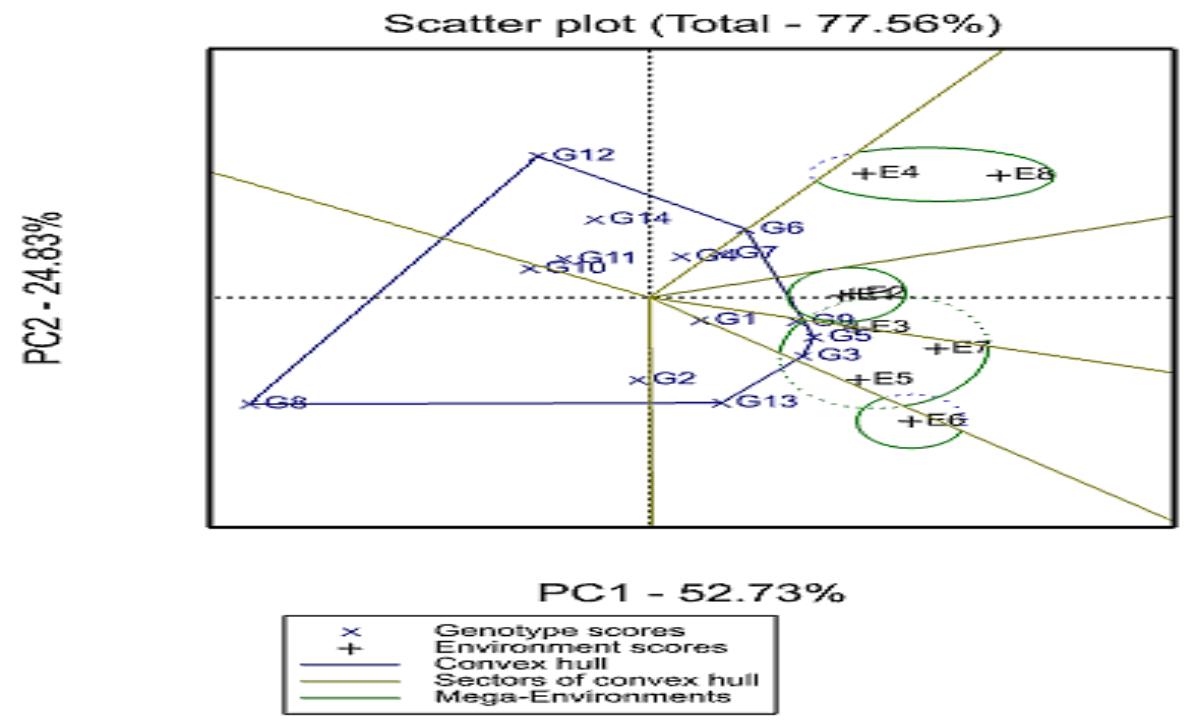

Figure 4. The which-won-where view of the GGE biplot to show which genotypes performed better in which environment for grain yield. G1-G14 are the genotypes; E1 -E8 are the environments.

\section{Heat susceptibility index (HSI):}

The HSI estimates ranged among genotypes from 0.36 for Sids 12 to 1.39 for Misr 2 (Table 6). The genotypes Sids 12, Shandaweel 1, Line 1, Gemmiza 12 and Sakha 94 recorded low HSI (HSI<1). Meanwhile, the genotypes Misr 2, Sids 14, Misr 1 and Gemmiza 9 had high HSI values (HSI >1). 
Table 6. Mean grain yield, relative grain yield to average and heat susceptibility (SI) index for grain yield of the studied wheat genotypes

\begin{tabular}{|c|c|c|c|}
\hline Genotype & $\begin{array}{c}\text { Mean grain yield } \\
\text { (ton ha-1) }^{\text {) }}\end{array}$ & Relative grain yield to average (\%) & Susceptibility index \\
\hline Misr 1 & 9.84 & 3.97 & 1.12 \\
\hline Misr 2 & 9.33 & -1.39 & 1.39 \\
\hline Misr 3 & 10.53 & 11.27 & 1.06 \\
\hline Sakha 94 & 9.69 & 2.35 & 0.88 \\
\hline Sakha 95 & 10.52 & 11.14 & 1.02 \\
\hline Line 1 & 10.03 & 5.94 & 0.66 \\
\hline Line 2 & 9.88 & 4.39 & 0.74 \\
\hline Giza 163 & 7.02 & -25.79 & 1.90 \\
\hline Giza 171 & 10.35 & 9.35 & 0.93 \\
\hline Gemmiza 9 & 8.87 & -6.26 & 1.11 \\
\hline Gemmiza 12 & 8.87 & -6.30 & 0.88 \\
\hline Sids12 & 8.63 & -8.84 & 0.36 \\
\hline Sids 14 & 9.90 & 4.60 & 1.28 \\
\hline Shandaweel 1 & 9.05 & -4.42 & 0.64 \\
\hline
\end{tabular}

\section{DISCUSSION}

The analysis of variance showed significant differences due to years reflected the differences in climate conditions during the two growing seasons (Fig. 1). The significance of differences among genotypes and their interactions with sowing date and year indicated that genotypes ranked differently via sowing dates. These results coincide with the findings of Talukder et al. (2014), Menshawy et al. (2015), Al-Otayk et al. (2019) and Hagras (2019).

\section{Year and sowing date effect:}

This study indicated that delaying sowing date after $5^{\text {th }}$ Dec. recorded a reduction in most studied characteristics. The mean values for grain yield, $\mathrm{KS}^{-1}$, plant height and SY did not differ significantly under both the first and second sowing date. These results may be due to the appropriate temperature at different developmental stages. The third sowing date ( $5^{\text {th }}$ January) recorded the highest mean values for $\mathrm{SM}^{-2}$ and harvest index. Although the third sowing date recorded the highest means for $\mathrm{SM}^{-2}$ and $\mathrm{KS}^{-1}$ but this did not reflect in higher grain yield. On the other hand, the fourth sowing date ( $5^{\text {th }}$ February) recorded the least mean values for all studied characters except for GFR. Thus the late-sowing recorded the least number of days for earliness characters and growing degree days which negatively affected yield components and hence the grain yield. The positively impacts the wheat grain yield in an optimum sowing date, causing better adjustment to the phonology, physiology and ecological conditions (Menshawy et al., 2015, Wahid et al., 2017, Hagras 2019 and Ray \& Ahmed, 2019). Different reasons were reported for grain yield reductions under late sowing (heat stress), especially during GFP. The reduction in grain yield in different sowing dates was reported to be due to many reasons; Zhao et al. (2008) to the reduction in activities of vital enzymes involved in starch accumulation; Hedhly et al. (2009) to the effect on pollen composition, morphology, quantity, metabolism and pollen tube growth rate; Riaz- Ud-Din et al. (2010) to be due to the reduction in $\mathrm{SM}^{-2}$ and grain yield and shortened DH, DM and GFP and Cossani \& Reynolds (2012) to abnormal anther formation in a high percentage of florets.

\section{Genotype performance:}

Giza 163 cultivar recorded the tallest plants with an insignificant difference with both Misr 2 and Sids 14 . The cultivar Misr 3 was superior overall genotypes for grain yield, SM-2, and SY; 10.529 ton, 552 spikes and 20.164 ton, respectively. The following cultivars recorded the highest values for specific characters with insignificant differences among them; Misr 3, Sakha 95, Giza 171 and Line 1 in grain yield; Misr 1, Misr 2, Misr 3, Shandaweel 1 and Sakha 95 in SM-2; Giza 171, Misr 2, Shandaweel 1, Sids 14, Gemmiza 9 and Gemmiza 12 in KS ${ }^{-1}$; Line 1, Sakha 95, Sids 14 and Misr 3 in TKW; Misr 3, Sids 14, Misr 2 and Gemmiza 9 in SY; Line 2, Line 1 and Sakha 94 in harvest index. It was interesting to notice that, Line 1 was early by 15 days in heading, 13 days in both booting and anthesis and 8 days in maturity and did not differ significantly in grain yield with Misr 3 (10.025 and 10.529 ton, respectively). These results coincide with the findings of Mondal et al. (2016) who reported that early maturing genotypes are an excellent crop adaptation approach in regions suffering from terminal and continual high-temperature stress. Many researchers reported significant differences among genotypes for earliness and agronomic characters (Talukder et al., 2014, Menshawy et al., 2015, Wahid et al., 2017, Hagras 2019 and Al-Otayk et al., 2019).

\section{Interaction effects:}

$5^{\text {th }}$ Dec. sowing date is suitable for all tested genotypes except Misr 1 as their grain yield did not record a significant reduction comparing to $5^{\text {th }}$ Nov. sowing date. This is an advantage of saving one month time and irrigation water. On the other hand, Misr 3 is the best choice if farmer has to plant on $5^{\text {th }}$ Nov. as he can get about $9 \%$ higher grain yield. Generally, the tested wheat genotypes can be divided into three groups: Group 1; include the two cultivars Sakha 95 and Giza 171 where they generally performed well when planted starting from $5^{\text {th }}$ Nov. to $5^{\text {th }}$ Feb. Group 2; include the two cultivars Misr 3, Sids 14 , where they performed well when planted starting from $5^{\text {th }}$ Nov. to $5^{\text {th }}$ Jan. Group 3 ; include the early maturing genotypes, Line 1 and Line 2 where they recorded the lowest grain yield reduction when planted staring from $5^{\text {th }}$ Jan. to $5^{\text {th }}$ Feb. Also, the studied wheat genotypes were different responses for different thermo-natural environments, indicating the importance of evaluating genotypes in different environments in order to determine the best genotype for a given environment. Similar results were obtained by Talukder et al. (2014) AlMenshawy et al. (2015) Wahid et al. (2017) Al-Otayk et al. (2019) and Hagras (2019). 


\section{Stability analysis:}

Identifying stable, high-yielding genotypes is a very important task for breeding program and food security. The yield potentiality of a genotype is controlled by three factors, i.e., genotypic main effects (G), environmental main effects (E) and their interaction. Genotype $x$ environment interaction (GEI) is considered as the variation that cannot be explained directly by genotypic or environmental components (Warzecha et al., 2011). Both GGE biplot analyses and ranking of genotypes (Figures 2 \&3) confirmed the superiority and stability of the three cultivars Sakha 95, Misr 3 and Giza 171 under the tested sowing dates. This finding might be due to stability in number of spikes and TKW in both Misr 3 and Sakha 95 and for number of kernels per spike in Giza 171. One of the most attractive features of GGE biplot is its ability to show the "which-won-where" pattern of a genotype by environment dataset as it graphically addresses important concepts such as cross-over GE, megaenvironment differentiation, specific adaptation, etc. (Yan and Tinker 2006). The polygon view of the GGE biplot (Figure 4) indicates the best genotype(s) in each environment and groups of environments (Yan et al., 2000 and Yan and Hunt 2001). Sakha 95, Misr 3 and Giza 171 cultivars suitable for planted in a wide range of planting date (from $5^{\text {th }}$ Nov. to $5^{\text {th }}$ Jan.) while, early maturing Line 1 can be recommended for late sowing ( $5^{\text {th }}$ Dec.). On the other hand, the remaining genotypes shows their high yield potentiality if planted on $5^{\text {th }}$ Dec.

Heat susceptibility index:

The relative performance of yield traits under heat-stressed (late sowing) and non-stressed environments (optimum sowing) has been widely used as an indicator to identify heat-tolerant wheat genotypes (Sharma et al., 2016). Heat susceptibility index (HIS), an index for evaluating heat stress, is a major requirement for traditional breeding. Low stress susceptibility index estimate $(\mathrm{HSI}<1)$ is synonymous with higher stress tolerance (Fisher \& Mourer 1978). The genotypes Sids 12, Shandaweel 1 , Line 1, Gemmiza 12 and Sakha 94 can be labeled as heat-tolerant genotypes while, Misr 2, Sids 14, Misr 1 and Gemmiza 9 can be considered as heat-sensitive one. The early maturing genotypes, Line 1 and Gemmiza 12 recorded low HIS values (0.66 and 0.74 respectively) confirming the previous finding as these two genotypes seemed to be fit for unfavorable conditions (late sowing). Misr 2, which is the latest genotype in heading recorded the highest HSI value (1.39), indicating that this cultivar is very sensitive to late sowing dates. These results are consistent with the findings of Menshawy (2007), Talukder et al. (2014) and Hagras (2019) where they reported that early maturing genotypes might be more suitable for late planting. On the other hand, Menshawy (2008) and Hagras (2019) reported that late genotypes in heading date are more suitable for early planting.

\section{CONCLUSION}

Generally, the tested genotypes were divided into three groups: Group 1; include the two cultivars Sakha 95 and Giza 171 where they generally performed well when planted starting from 5th Nov. to 5th Feb. Group 2; include the four cultivars Misr 3, Sids 14, where they performed well when planted starting from 5th Nov. to 5th Jan. Group 3; include the early maturing genotypes, Line 1 and Line 2 where they recorded the lowest grain yield reduction when planted staring from 5 th Jan. to 5 th Feb. According to stability analyses, Misr 3, Sakha 95 and Giza 171 recorded the highest yield, 10.53, 10.52 and 10.35-ton ha-1, over the grand mean yield with the regression coefficient values more than 1 so were good for a favorable environment (optimum sowing date). The genotypes Line 1 and Line 2 had a regression coefficient value lower than 1 and were above the average of yield that seemed to be fit for the unfavorable condition. The new wheat lines Line 1 and Line 2 had remarkable superiority for all earliest characters with an insignificant difference in grain yield with Misr 3 for Line 1.

\section{ACKNOWLEDGEMENT}

The authors are thanks to the Wheat Research Department for the financial and scientific support and support provided by Prof. A.M. Menshawy; Wheat Research Department, Field Crops Research Institute, Agriculture Research Centre, Egypt during data analysis.

\section{REFERENCES}

Akcura, M. \& Kaya Y. (2008). Nonparametric stability methods for interpreting genotype by environment interaction of bread wheat genotypes (Triticum aestivum L.). Genetics and Molecular Biology, 31 (4), 906-913. DOI: 10.1590/S141547572008005000004.

Al-Otayk, S.M. (2019). Evaluation of agronomic traits and assessment of genetic variability in some popular wheat genotypes cultivated in Saudi Arabia. Australian Journal of Crop Science, 13(06), 847-856. DOI: 10.21475/ajcs.19.13.06.p1329.

Anderson, W.K. \& Smith, W.R. (1990). Yield advantage of two semi-dwarf compared with two tall wheats depends on sowing time. Australian Journal of Agricultural Research, (41), 811-826. DOI: 10.1071/AR9900811.

Angus, J.F. (2006). Tools for managing wheat canopies. Paper presented at the GRDC Research Update, WaggaWagga, 21-22nd February 2006.

Ansary, A.H., Khushak, A.M., Sethar, M.A., Ariam, N.A. \& Emon, M.Y.M. (1989). Effect of sowing dates on growth and yield of wheat cultivars. Pakistan Journal of Scientific and Industrial Research, (32), 39- 42.

Bannayan, M., EyshiRezaei, E. \& Hoogenboom, G. (2013). Determining optimum sowing dates for rainfed wheat using the precipitation uncertainty model and adjusted crop evapotranspiration. Agriculture Water Management, (126), 56-63. DOI: 10.1016/j.agwat.2013.05.001.

Bassu, S., Asseng, A., Motzo, R. \& Giunta, F. (2009). Optimizing sowing date of durum wheat in a variable Mediterranean environment. Field Crops Research, (111), 109-118. DOI: 10.1016/j.fcr.2008.11.002.

Brdar, M.D., Kraljevic-Balalic, M.M. \& Kobiljski, B.D. (2008). The parameters of grain filling and yield components in common wheat (Triticum aestivum L.) and durum wheat (Triticum turgidum L. var. durum). Central European Journal of Biology, 3(1), 75-82. DOI: 10.2478/s11535-007-0050-x. 
Connor, D.J., Theiveyanathan, S. \& Rimmington, G.M. (1992). Development, growth, water-use and yield of a spring and a winter wheat in response to time of sowing. Australian Journal of Agricultural Research, (43), 493-516. DOI: 10.1071/AR9920493.

Cossani, C.M. \& Reynolds, M.P. (2012). Physiological traits for improving heat tolerance in wheat. Plant Physiology, (160), 1710-1718. DOI: $10.1104 /$ pp.112.207753.

Cuevas, J., Crossa, J., Montesinos-López, O.A., Burgueno, J., Pérez-Rodríguez, P. \& De los Campos, G. (2017). Bayesian genomic prediction with genotype $\times$ environment interaction kernel models. G3: Genes, Genomes, Genetics, (7), 41-53. DOI: 10.1534/g3.116.035584.

Esuma, W., Kawuki, R.S., Herselman, L. \& Labuschagne, M.T. (2016). Stability and genotype by environment interaction of pro vitamin A, carotenoid and dry matter content in cassava in Uganda. Breeding Science,(66), 434-443. DOI: 10.1270/jsbbs.16004.

FAO. (2019). FAOSTAT http:// www. fao.org/ faostat/en/\#data/QC/visualize.

Fisher, R.A. \& Maurer, R. (1978). Drought resistance in spring wheat cultivars. I. Grain yield responses. Australian Journal of Agricultural Research, (29), 897-912. DOI: 10.1071/AR9780897.

Flohr, B.M., Hunt, J.R., Kirkegaard, J.A. \& Evans, J.R. (2017). Water and temperature stress define the optimal flowering period for wheat in south-eastern Australia. Field Crops Research, (209), 108-119. DOI: 10.1016/j.fcr.2017.04.012.

Gomez M., H. \& Richards, R.A. (1997). Effect of early sowing on development in wheat isolines differing in vernalisation and photoperiod requirements. Field Crops Research, (54), 91-107.DOI: 10.1016/S0378-4290(97)00057-9.

Hagras, A. A. I. (2019). Response of some early maturing bread wheat genotypes to late sowing date. Egyptian Journal of Plant Breeding, 23(6): 1195-1213.DOI: 10.21608/ipp.2019.71521.

Harris, F. A. J. (2015). The Relationship Between Vigor and Earliness in Wheat (Triticum aestivum L.). Ph.D. thesis, Charles Sturt University, WaggaWagga, Australia.

Hedhly, A., Hormaza, J.I. \& Herrero, M. (2009) Global warming and sexual plant reproduction. Trends Plant Science, (14), 30-36. DOI: 10.1016/j.tplants.2008.11.001.

Hickey, L.T., Hafeez, A.N., Robinson, H., Jackson, S.A., Leal-Bertioli, S.C.M., Tester, M., Gao, C., Godwin, D., Hayes, B.J. \& Wulff, B.B.H. (2019). Breeding crops to feed 10 billion. Nature, 37(7),744-754.DOI: 10.1038/s41587-019-0152-9.

Inamullah, N.S, Haq, Z. \& Khan, F.U. (2007) An analysis of the planting dates effect on yield and yield attributes of spring wheat. Sarhad Journal of Agriculture, 23(2), 271-279.

Kaya, Y., Akcura, M. \& Taner, S. (2006). GGE-biplot analysis of multi-environment yield trials in bread wheat. Turkish Journal of Agriculture, (30), 325-337. https://journals.tubitak.gov.tr/agriculture/issues/tar-06-30-5/tar-30-5-3-0604-6.pdf

Li, F., Wen, W., Liu, J., Zhang, Y., Cao, S., He, Z., Rasheed, A., Jin, H., Zhang, C., Yan, J., Zhang, P., Wan, Y. \& Xia, X. (2019). Genetic architecture of grain yield in bread wheat based on genome-wide association studies. BMC Plant Biology,(19),168. DOI: 10.1186/s12870-019-1781-3.

Menshawy, A.M.M. (2007). Evaluation of some early bread wheat genotypes under different sowing dates: 2. Agronomic characters. Fifth Plant Breeding Conference (May 6). Egyptian Journal of Plant Breeding, 11 (1), 41-55 Special Issue.

Menshawy, A.M.M. (2008). Response of six bread wheat genotypes to different sowing dates. Egyptian Journal of Agriculture Research, 86 (3), 957-971.

Menshawy, A.M.M., Al-Soqeer, A.A. \& Al-Otayk, S.M. (2015). Earliness, yield and heat sensitivity in bread wheat under natural heat stress. Egyptian Journal of Agriculture Research, 93(2A)

Mondal, S., Singh, R.P., Masonb, E.R., Huerta-Espinoa, J., Autriquea, C.E., Joshid, A.K. (2016). Grain yield, adaptation and progress in breeding for early-maturing and heat-tolerant wheat lines in South Asia. Field Crops Research, (192), 78-85. DOI: 10.1016/i.fcr.2016.04.017.

MSTATC (1990). A Microcomputer Program for the Design. Management, and Analysis of Agronomic Research Experiments. Michigan State Univ.

Nazim Ud-Dowla ,N.N.U., Edwards, I., Hara, G. O., Islam, S. \& Ma, W. (2018). Developing wheat for improved yield and adaptation under a changing climate: optimization of a few key genes. Engineering, (4), 514-522. DOI: 10.1016/i.eng.2018.06.005.

Ortiz-Monasterio, J.I., Dhillon, S.S. \& Fischer, R.A. (1994). Date of sowing effects on grain yield and yield components of irrigated spring wheat cultivars and relationships with radiation and temperature in Ludhiana, India. Field Crops Research, (37), 169-184. DOI: 10.1016/0378-4290(94)90096-5.

Owiss, T., Pala, M. \& Ryan. J. (1999) Management alternatives for improved durum wheat production under supplemental irrigation in Syria. European Journal of Agronomy, 11, 255-266. DOI: 10.1016/S1161-0301(99)00036-2.

Pacheco, A., Vargas, M., Alvarado, G., Rodriguez, F., Crossa, J. \& Burgueno, J. (2018). GEA-R (Genotype Environment Analysis with R for Windows) Verion 4. Available online: http://hdl.handle.net/11529/10203.

Quan, S., Li, Y., Song, J., Zhang, T. \& Wang, M. (2019). Adaptation to climate change and its impacts on wheat yield: perspective of farmers in Henan of China. Sustainability, (11), 19-28. DOI: 10.3390/su11071928.

Radmehr, M., Ayeneh, G.A. \& Mamghani, R. (2003). Responses of late, medium and early maturity bread wheat genotypes to different sowing date. I. Effect of sowing date on phonological, morphological, and grain yield of four breed wheat genotypes. Iran. J. Seed. Sapling, 21 (2), 175-189.

Ray, J. \& Ahmed, J.U. (2019). Grain growth and yield potential of wheat genotypes under late sown heat stressed condition. Fundamental and Applied Agriculture, 4(1), 671-679. DOI: 10.5455/faa.1122.

Riaz- Ud-Din, R., Subhani, G.M., Ahmad, N., Hussain, M. \& Ur- Rehman, A. (2010). Effect of temperature on development and grain formation in spring wheat. Pakistan Journal of Botany, 42 (2), 899-906. http://www.pakbs.org/pibot/PDFs/42(2).

Ribeiro, T.L.P., Cunha, G.R., Pires, J.L. F. \& Pasinato, A. (2009). Phonological responses of Brazilian wheat cultivars to vernalization and photoperiod. Pesquisa Agropecuária Brasileira, 44 (11), 1383-1390. DOI: 10.1590/S0100-204X2009001100012. 
Rodríguez, A., Ruiz-Ramos, M., Palosuo, T., Carter, T.R., Fronzek, S., Lorite, I.J., Ferrise, R., Pirttioja, N., Bindif, M., Baranowski, P., Buis, S., Cammarano, D., Chen, Y., Dumont, B., Ewert, F., Gaiser, T., Hlavinkal, P., Hoffmann, H., Höhn, J.G., Jurecka, F., Kersebaum, K.C., Krzyszczak, J., Lanan, M., Mechiche-Alami, A., Minet, J., Montesino, M., Nendel, C., Porter, J.R., Ruget, F., Semenov, M.A., Steinmetz, Z., Stratonovitch, P., Supit, I., Tao, F., Trnka, M. \& de Wit A.,Rötterv, R.P.W. (2019). Implications of crop model ensemble size and composition for estimates of adaptation effects and agreement of recommendations. Agricultural and Forest Meteorology, (264), 351-362. DOI: 10.1016/i.agrformet.2018.09.018.

Sharma, D., Singh., R., Rane, J., Gupta, V.K., Mamrutha, H.M. \& Tiwari, R. (2016). Mapping quantitative trait loci associated with grain filling duration and grain number under terminal heat stress in bread wheat (Triticum aestivum L.), Plant Breeding, (135), 538545. DOI:10.1111/pbr.12405.

Silva, R.R., Benin, G., Almeida, J.L., Fonseca, I.C.B. \& Zucareli, C. (2014). Grain yield and baking quality of wheat under different sowing dates. Acta Scientiarum Agronomy, 36(2), 201-210. DOI: 10.4025/actasciagron.v36i2.16180.

Singh, P. \& Narayanan, S.S. (2000). Biometrical Techniques in Plant Breeding. Kalyani Publishers, New Delhi.

Stapper, M. \& Fischer, R.A. (1990). Genotype, sowing date and plant spacing influence on high-yielding irrigated wheat in southern New South Wales. I. Phasic development, canopy growth and spike production. Australian Journal of Agricultural Research, (41), 997-1019. DOI: 10.1071/AR9900997.

Talukder, A.S.M., McDonald, G.K. \& Gill, G.S. (2014). Effect of short-term heat stress prior to flowering and early grain set on the grain yield of wheat. Field Crops Research,160, 54-63. Effect of short-term heat stress prior to flowering and early grain set on the grain yield of wheat. Field Crops Research, (160), 54-63. DOI: 10.1016/j.fcr.2014.01.013.

USDA (2020) (United States Department of Agriculture), Foreign Agriculture Service. Grain and Feed Annual: Egyptian Wheat Imports Hold Steady Despite Increased Local Production. EG2020-0005, March 15,2020. https://apps.fas.usda.gov/newgainapi/api/Report/ DownloadReportByFileName?fileName=Grain\%20and\%20Feed\%20Annual_Cairo_Egypt_03-15-2020

Wahid, S.A., Al-Hilfy, I.H.H. \& Al-Abodi, H.M.K. (2017). Effect of sowing dates on the growth and yield of different wheat cultivars and their relationship with accumulated heat units. American-Eurasian Journal of Sustainable Agriculture, 3(11), 7-13. http://www.aensiweb.net/AENSIWEB/aejsa/aejsa/2017/May/7-13.pdf

Warzecha, T., Adamski, T., Kaczmarek, Z., Surma, M., Chełkowski, J., Wiśniewska, H., Krystkowiak, K. \& Uczyńska, A. (2011). Genotype-by-environment interaction of barley DH lines infected with Fusarium culmorum (WG Sm.) Sacc. Field Crops Research, (120), 21-30. DOI: 10.1016/i.fcr.2010.08.009.

Xie, W., Xiong, W., Pan, J., Ali, T., Cui, Q., Guan, D., Meng, J., Mueller, N. D., Lin, E. \& Davis, S.J. (2018). Decreases in global beer supply due to extreme drought and heat. Nature Plants, (4), 964-973. DOI: 10.1038/s41477-018-0263-1.

Yan, W. \& Hunt, L.A. (2001). Interpretation of genotype by environment interaction for winter wheat yield in Ontario. Crop Science, 41:19-25. DOI: 10.2135/cropsci2001.41119x.

Yan, W. \& Tinker, N.A. (2006). Biplot analysis of multi-environment trial data: Principles and applications. Can. J. Plant Science, (86), 623-645. DOI: 10.4141/P05-169.

Yan, W., Hunt, L.A., Sheng, Q. \& Szlavnics, Z. (2000). Cultivar evaluation and mega-environment investigation based on GGE biplot. Crop Science, (40), 596-605. DOI: 10.2135/cropsci2000.403597x.

Zhao, H., Dai, T., Jiang, D. \& Cao, W. (2008). Effects of high temperature on key enzymes involved in starch and protein formation in grains of two wheat cultivars. Journal of Agronomy and Crop Science, (194), 47-54. DOI: 10.1111/j.1439-037X.2007.00283X.

Zhongfu, N., Hongjian, L., Yue, Z., Huiru, P., Zhaorong, H., Mingming, X. \& Qixin, S. (2018). Genetic improvement of heat tolerance in wheat: Recent progress in understanding the underlying molecular mechanisms. The Crop Journal, (6), 32-41. DOI: 10.1016/i.cj.2017.09.005.

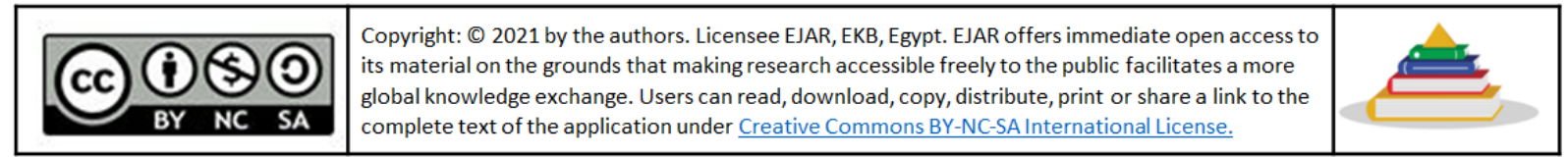




\title{
سلوك بعض أصناف قمح الخبز المصري في بيئات حرارية وضوئية طبيعية مختلفة
}

\author{
سيدهم عبدالخالق محمد عبدالخالق، خالد الدمرداش إبراهيم رجب، عادل عبدالعزيز هجرس

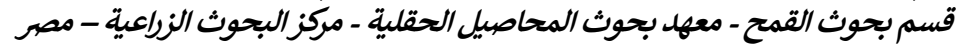 \\ sedhom aiad@yahoo.com:بريد المؤلف المراسل
}

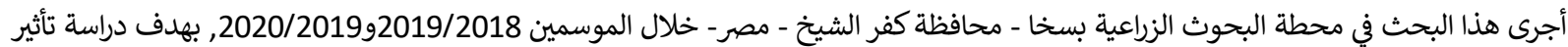

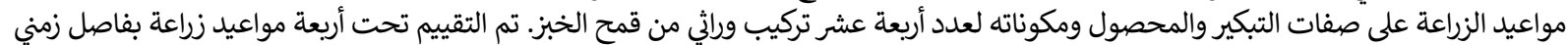

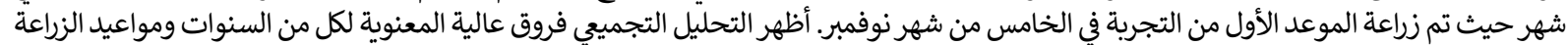

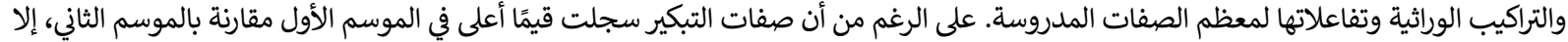

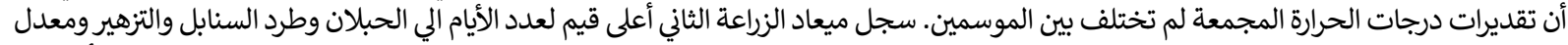

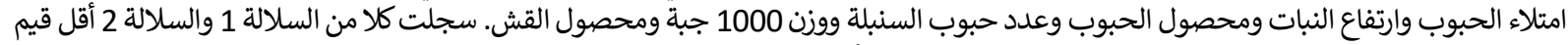

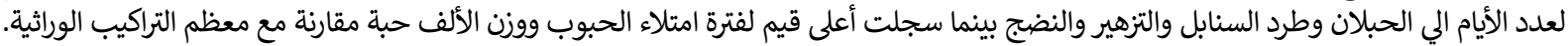

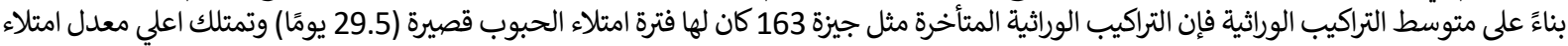

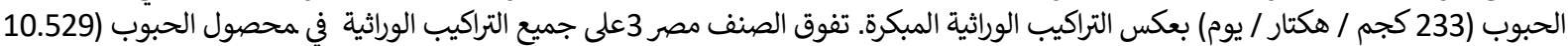

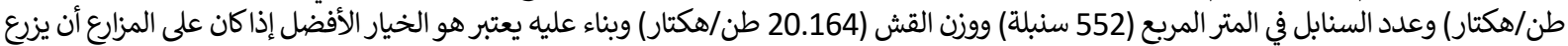

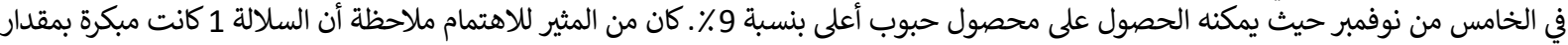

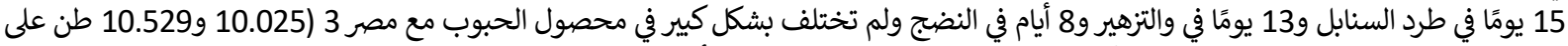

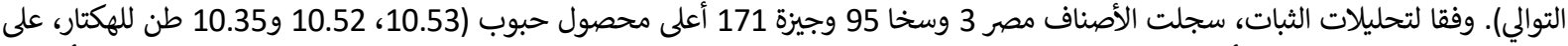

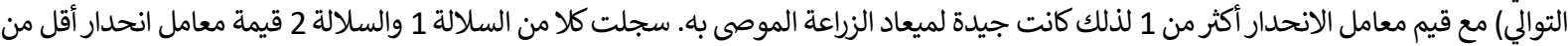

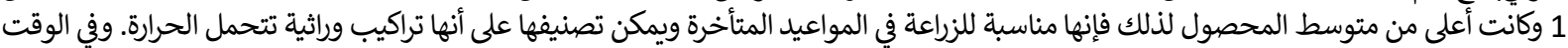

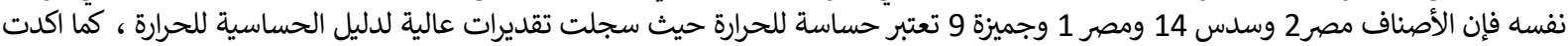

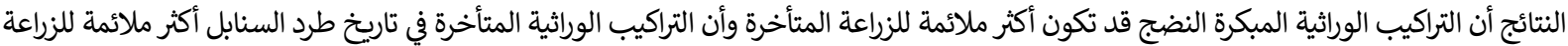




\section{Supplement Tables}

Table S1. Mean square values for days to booting (DB), anthesis (DA), heading (DH), and maturity (DM), grain filling period (GFP), and rate (GFR) and growing degree days (GDD) for the fourteen bread wheat genotypes.

\begin{tabular}{|c|c|c|c|c|c|c|c|c|}
\hline \multirow{2}{*}{ Source of variations } & \multirow{2}{*}{ df } & \multicolumn{7}{|c|}{ Mean square } \\
\hline & & DB & DH & DA & DM & GP & GR & GDD \\
\hline $\operatorname{Year}(Y)$ & 1 & $2421.4^{* *}$ & $2095.0 * *$ & $2964.3 * *$ & $2242.3^{* *}$ & $50.3^{* *}$ & $27445.1^{* *}$ & $217.3^{* *}$ \\
\hline Sowing date(SD) & 3 & $7408.9 * *$ & $9021.9 * *$ & $13402.4^{* *}$ & $33139.8^{* *}$ & $6393.4^{* *}$ & $89464.3 * *$ & $1351050 * *$ \\
\hline$Y \times S D$ & 3 & $65.7^{* *}$ & $100.7^{* *}$ & $72.3^{* *}$ & $36.7 * *$ & $92.5 * *$ & $14423.2^{* *}$ & $17697.5^{* *}$ \\
\hline $\operatorname{Rep}(S D \times Y)$ & 16 & $14.4^{* *}$ & $6.9 * *$ & $8.6^{* *}$ & $5.7^{* *}$ & 3.4 & 1277.2 & $1684.5^{* *}$ \\
\hline Genotype (G) & 13 & $1811.4^{* *}$ & $1679.7^{* *}$ & $1511.2^{* *}$ & $373.8^{* *}$ & $433.0 * *$ & $9117.0^{* *}$ & $369395.3^{* *}$ \\
\hline $\mathbf{Y} \times \mathbf{G}$ & 13 & $15.7^{* *}$ & $10.3^{* *}$ & $21.8^{* *}$ & $6.8^{* *}$ & $13.6 * *$ & $2195.2^{* *}$ & $2239.1^{* *}$ \\
\hline $\mathbf{S D} \times \mathbf{G}$ & 39 & $190.5^{* *}$ & $191.4^{* *}$ & $148.0 * *$ & $40.9 * *$ & $46.2 * *$ & $5460.1 * *$ & $26245.9 * *$ \\
\hline $\mathbf{Y} \times \mathbf{S D} \times \mathbf{G}$ & 39 & $21.1^{* *}$ & $10.4^{* *}$ & $8.0^{* *}$ & $7.3^{* *}$ & $6.4^{* *}$ & 1137.7 & $1971.6 * *$ \\
\hline Error & 208 & 3.96 & 1.98 & 2.01 & 1.80 & 2.74 & 846.07 & 527.39 \\
\hline CV\% & - & 2.65 & 1.64 & 1.49 & 0.99 & 4.14 & 12.14 & 1.85 \\
\hline
\end{tabular}

$*$ and ${ }^{* *}=$ significant at 0.05 and 0.01 levels of probability, respectively.

Table S2. Mean square values for plant height, grain yield, number of spikes per square meter $\left(\mathrm{SM}^{-2}\right)$, number of kernels per spike $\left(\mathrm{KS}^{-1}\right)$, $1000-k e r n e l$ weight (TKW), straw yield and harvest index for the fourteen bread wheat genotypes.

\begin{tabular}{|c|c|c|c|c|c|c|c|c|}
\hline \multirow{2}{*}{ Sarceofleritions } & \multirow{2}{*}{ df } & \multicolumn{7}{|c|}{ Mean square } \\
\hline & & Plant height & Grain yield & $\mathrm{SM}^{-2}$ & $\mathrm{KS}^{-1}$ & TKW & Straw yield & Harvest index \\
\hline Year $(Y)$ & 1 & $8034.1^{* *}$ & $67.95 * *$ & $1238060.3^{* *}$ & $8990.01 * *$ & $255.52^{* *}$ & $678.70^{* *}$ & $2591.96 * *$ \\
\hline Sowing date(SD) & 3 & $10738.6 * *$ & $313.12 * *$ & $105702.6 * *$ & $995.22 * *$ & $1821.87^{* *}$ & $930.27^{* *}$ & $263.62 * *$ \\
\hline $\mathrm{Y} \times \mathrm{SD}$ & 3 & $306.65^{* *}$ & $23.99 * *$ & $103302.4 * *$ & $284.57^{* *}$ & $230.48^{* *}$ & $200.98^{* *}$ & $685.01 * *$ \\
\hline $\operatorname{Rep}(S D \times Y)$ & 16 & $49.61 * *$ & 1.90 & 8901.18 & $114.26^{* *}$ & 20.98 & $13.28 * *$ & $26.92 * *$ \\
\hline Genotype (G) & 13 & $1060.4^{* *}$ & $21.15^{* *}$ & $64346.3 * *$ & $599.25^{* *}$ & $295.81^{* *}$ & $79.51 * *$ & $310.54^{* *}$ \\
\hline $\mathbf{Y} \times \mathbf{G}$ & 13 & $62.82 * *$ & $3.55^{* *}$ & $12155.8^{*}$ & $140.67^{* *}$ & $49.55^{* *}$ & $18.25^{* *}$ & $34.88 * *$ \\
\hline$S D \times G$ & 39 & $96.77 * *$ & $3.92 * *$ & $14825.1^{* *}$ & $119.13 * *$ & $34.24 * *$ & $14.39 * *$ & $78.86 * *$ \\
\hline $\mathbf{Y} \times \mathbf{S D} \times \mathbf{G}$ & 39 & $61.30 * *$ & $1.73^{*}$ & $14751.1^{* *}$ & $81.90 * *$ & 32.09* & 5.25 & 17.72 \\
\hline Error & 208 & 22.84 & 1.13 & 6148.00 & 45.86 & 19.88 & 3.84 & 12.52 \\
\hline $\mathrm{CV} \%$ & - & 4.36 & 11.24 & 16.18 & 11.64 & 10.58 & 11.07 & 10.07 \\
\hline
\end{tabular}

* and ${ }^{* *}=$ significant at 0.05 and 0.01 levels of probability, respectively. 
Table S3. Mean values of days to booting, days to anthesis, plant height and straw yield for fourteen bread wheat genotypes grown under four sowing dates during 2018/2019 and 2019/2020 growing seasons.

\begin{tabular}{|c|c|c|c|c|}
\hline Variables & Days to booting & Days to anthesis & Plant height $(\mathrm{cm})$ & Straw yield ( $t$ ha-1) \\
\hline \multicolumn{5}{|c|}{ Year } \\
\hline $2018 / 2019$ & 77.7 & 98.3 & 114.4 & 19.125 \\
\hline $2019 / 2020$ & 72.4 & 92.3 & 104.7 & 16.283 \\
\hline F test & $* *$ & $* *$ & $* *$ & $* *$ \\
\hline \multicolumn{5}{|c|}{ Sowing date } \\
\hline Nov. $5^{\text {th }}$ & 74.4 & 102.7 & 117.8 & 20.118 \\
\hline Dec. $5^{\text {th }}$ & 86.1 & 107.0 & 118.4 & 20.660 \\
\hline Jan. $5^{\text {th }}$ & 76.3 & 93.1 & 107.8 & 16.473 \\
\hline Feb. $5^{\text {th }}$ & 63.2 & 78.5 & 94.2 & 13.564 \\
\hline LSD $_{0.05}$ & 0.60 & 0.43 & 1.44 & 0.59 \\
\hline \multicolumn{5}{|c|}{ Genotype } \\
\hline Misr 1 & 74.2 & 94.7 & 106.9 & 17.814 \\
\hline Misr 2 & 79.8 & 100.1 & 119.2 & 19.446 \\
\hline Misr 3 & 75.4 & 95.2 & 106.3 & 20.164 \\
\hline Sakha 94 & 78.1 & 96.9 & 110.0 & 15.352 \\
\hline Sakha 95 & 78.9 & 97.1 & 113.5 & 17.594 \\
\hline Line 1 & 60.1 & 82.1 & 97.9 & 16.037 \\
\hline Line 2 & 59.0 & 81.0 & 103.8 & 14.943 \\
\hline Giza 163 & 94.3 & 113.8 & 120.0 & 18.129 \\
\hline Giza 171 & 74.4 & 94.6 & 112.3 & 18.630 \\
\hline Gemmiza 9 & 80.9 & 100.5 & 111.0 & 19.229 \\
\hline Gemmiza 12 & 73.9 & 93.0 & 105.0 & 17.108 \\
\hline Sids12 & 68.7 & 90.3 & 100.6 & 14.784 \\
\hline Sids 14 & 77.6 & 98.1 & 117.3 & 19.861 \\
\hline Shandaweel 1 & 75.3 & 97.0 & 109.8 & 18.763 \\
\hline LSD $_{0.05}$ & 1.12 & 0.80 & 2.70 & 1.11 \\
\hline
\end{tabular}

Table S4. Mean squares of combined analysis of variance and proportion of sums of squares (SS\%) for grain yield.

\begin{tabular}{|c|c|c|c|}
\hline Source of variations & df & Mean squares & $154.18^{* *}$ \\
\hline Environments (E) & 7 & 1.90 & 57.21 \\
\hline Error 1 & 16 & $21.15^{* *}$ & 1.61 \\
\hline Genotypes (G) & 13 & $2.93^{* *}$ & 14.57 \\
\hline GEI & 91 & 1.13 & 12.48 \\
\hline Error 2 & 208 & & \\
\hline
\end{tabular}

* = Significant at 0.01 levels of probability. 
Table S5. Mean values over two years (2018/19 and 2019/20) for days to booting, days to anthesis, plant height and straw yield of fourteen bread wheat genotypes grown under four sowing dates.

\begin{tabular}{|c|c|c|c|c|c|c|c|c|c|c|c|c|c|c|c|c|}
\hline \multirow[b]{2}{*}{ Genotype } & \multicolumn{4}{|c|}{ Days to booting } & \multicolumn{4}{|c|}{ Days to anthesis } & \multicolumn{4}{|c|}{ Plant height (cm) } & \multicolumn{4}{|c|}{ Straw yield (t ha. ${ }^{-1}$ ) } \\
\hline & $\begin{array}{c}5^{\text {th }} \\
\text { Nov. }\end{array}$ & $\begin{array}{c}5^{\text {th }} \\
\text { Dec. }\end{array}$ & $\begin{array}{c}5^{\text {th }} \\
\text { Jan. }\end{array}$ & $\begin{array}{c}5^{\text {th }} \\
\text { Feb. }\end{array}$ & $\begin{array}{c}5^{\text {th }} \\
\text { Nov. }\end{array}$ & $\begin{array}{c}5^{\text {th }} \\
\text { Dec. }\end{array}$ & $\begin{array}{c}5^{\text {th }} \\
\text { Jan. }\end{array}$ & $\begin{array}{c}5^{\text {th }} \\
\text { Feb. }\end{array}$ & $\begin{array}{c}5^{\text {th }} \\
\text { Nov. }\end{array}$ & $\begin{array}{c}5^{\text {th }} \\
\text { Dec. }\end{array}$ & $\begin{array}{c}5^{\text {th }} \\
\text { Jan. }\end{array}$ & $\begin{array}{c}5^{\text {th }} \\
\text { Feb. }\end{array}$ & $\begin{array}{c}5^{\text {th }} \\
\text { Nov. }\end{array}$ & $\begin{array}{c}5^{\text {th }} \\
\text { Dec. }\end{array}$ & $\begin{array}{c}5^{\text {th }} \\
\text { Jan. }\end{array}$ & $\begin{array}{c}5^{\text {th }} \\
\text { Feb. }\end{array}$ \\
\hline Misr 1 & 76 & 86 & 74 & 61 & 106 & 105 & 91 & 78 & 116 & 117 & 103 & 92 & 21.2 & 21.2 & 14.8 & 14.0 \\
\hline Misr 2 & 89 & 88 & 76 & 66 & 115 & 111 & 95 & 79 & 133 & 123 & 117 & 105 & 23.1 & 20.9 & 18.4 & 15.4 \\
\hline Misr 3 & 75 & 88 & 76 & 63 & 102 & 106 & 94 & 78 & 116 & 111 & 103 & 95 & 22.3 & 23.9 & 18.3 & 16.1 \\
\hline Sakha 94 & 82 & 89 & 77 & 65 & 108 & 108 & 93 & 79 & 123 & 118 & 105 & 94 & 18.9 & 16.6 & 14.6 & 11.3 \\
\hline Sakha 95 & 87 & 88 & 77 & 64 & 111 & 107 & 93 & 79 & 128 & 122 & 109 & 95 & 22.6 & 20.1 & 15.8 & 11.8 \\
\hline Line 1 & 48 & 71 & 68 & 53 & 78 & 95 & 85 & 70 & 100 & 110 & 100 & 82 & 17.5 & 20.2 & 14.3 & 12.2 \\
\hline Line 2 & 48 & 69 & 66 & 52 & 76 & 94 & 85 & 70 & 103 & 113 & 110 & 89 & 15.3 & 19.2 & 13.5 & 11.8 \\
\hline Giza 163 & 110 & 100 & 86 & 82 & 136 & 124 & 104 & 92 & 130 & 126 & 117 & 108 & 20.4 & 18.3 & 15.9 & 18.0 \\
\hline Giza 171 & 68 & 88 & 78 & 65 & 98 & 108 & 94 & 80 & 121 & 123 & 108 & 98 & 19.3 & 23.3 & 17.9 & 14.1 \\
\hline Gemmiza 9 & 83 & 91 & 83 & 67 & 110 & 112 & 98 & 83 & 119 & 118 & 116 & 91 & 23.5 & 21.0 & 18.4 & 14.1 \\
\hline Gemmiza 12 & 71 & 87 & 76 & 62 & 100 & 104 & 91 & 77 & 113 & 116 & 102 & 89 & 17.8 & 20.8 & 17.5 & 12.3 \\
\hline Sids12 & 59 & 84 & 73 & 59 & 93 & 103 & 90 & 75 & 103 & 115 & 98 & 87 & 17.2 & 18.0 & 13.6 & 10.4 \\
\hline Sids 14 & 77 & 90 & 79 & 65 & 107 & 110 & 95 & 81 & 128 & 128 & 113 & 101 & 21.0 & 25.5 & 19.0 & 14.0 \\
\hline Shandaweel 1 & 70 & 88 & 80 & 63 & 102 & 111 & 96 & 79 & 117 & 118 & 109 & 95 & 21.6 & 20.4 & 18.6 & 14.4 \\
\hline LSD $_{0.05}$ & \multicolumn{4}{|c|}{2.3} & \multicolumn{4}{|c|}{1.6} & \multicolumn{4}{|c|}{5} & \multicolumn{4}{|c|}{2.2} \\
\hline
\end{tabular}

